\title{
Contribution of work ability and work motivation with performance and its impact on work productivity
}

\author{
Sri Hastari ${ }^{\mathbf{a}^{*}}$, Eva Mufidah ${ }^{\mathrm{a}}$, Paring Wahyudi ${ }^{\mathrm{a}}$ and Dwita Laksmita ${ }^{\mathrm{a}}$
}

${ }^{a}$ University of Merdeka Pasuruan, Indonesia

\section{H R O N I C L E}

\section{Article history:}

Received: June 20, 2020

Received in revised format:

August 302020

Accepted: September 18, 2020

Available online:

September 18, 2020

Keywords:

Work Ability

Motivation

Performance

Work Productivity

\section{A B S T R A C T}

One of the important tasks is to improve work ability, work motivation, performance and work productivity in business. The research objective is to examine the contribution and influence of work ability, work motivation, performance, and their impacts on work productivity. The research was conducted among all 105 cooperatives in the city of Pasuruan, East Java. The research method used survey methods and data analysis techniques using path analysis. The results showed that work ability and work motivation had significant effects on the performance $(\beta=0.226$, Sig. $=$ $0.000)$. Work ability, work motivation, and performance had significant effects on work productivity $(\beta=0.481, \alpha=0.000)$. The ability to work had a significant direct effect on the performance $(\beta=0.393$, Sig. $=0.000)$. Work ability had a significant direct effect on productivity $(\beta=0.578$, Sig. $=0.043)$. Performance had a significant direct effect on work productivity $(\beta=0.542, \alpha=0.000)$. Furthermore, work ability had a significant effect on work productivity through performance (tvalue $=2.083>1.983$ ). Finally, work motivation had a significant indirect effect on productivity through performance $(\mathrm{t}$-value $=2.921>1.983)$.

2021 by the authors; licensee Growing Science, Canada

\section{Introduction}

The role of cooperatives is very important, so it is no wonder that cooperatives can be found everywhere in all regions of Indonesia. Even in remote villages we can find cooperatives. For the people of Indonesia, cooperatives are familiar since we have experienced the services of cooperatives in order to get out of financial difficulties. Like other economic institutions, cooperatives are a form of alliance that carry out muamalah activities in the economic field. Cooperatives play an important role in Indonesian society, especially in the process of the Indonesian economy in the middle of society. Almost everyone knows cooperatives even though the definition of cooperative is understood differently, but basically it aims for the benefit of the community. The cooperative appears to have a relationship with the People's Economy which is currently being discussed by the government as well as the private sector. People's Economy is usually known as an economic concept that sided with the people. In this case what is meant is the little people. Of course, the people's economy is in great demand by the middle to lower classes who think that this understanding is the right understanding. It seems clear that cooperatives are related to People's Economy. The People's Economy takes the side of the small people and cooperatives strive for the economic needs of its members and have the aim of improving the welfare of its members. The role of cooperatives is very strategic in the Indonesian economy, so it needs to be the focus of national economic development in the future. It is hoped that structured and periodic empowerment of cooperatives will be able to align the structure of the national economy, encourage and accelerate national economic growth, and be able to reduce unemployment, reduce poverty and improve the distribution of people's income.

* Corresponding author.

E-mail address: diah 1wg@yahoo.com (S. Hastari) 
The development of cooperatives is currently supported by the development of small and medium enterprises in Pasuruan, especially in the city of Pasuruan, which is growing rapidly. In line with the increasing economy of the people in Pasuruan City, cooperatives are expected to help provide funds to finance and develop industrial, agricultural, trade and other nonfinancial sectors. Based on the description above, the researcher conducted research with the theme: Contribution of Ability and Work Motivation to Performance and Its Impact on Work Productivity.

\section{Literature review}

\subsection{Performance}

Performance or performance is a work result that can be achieved by a person or group of people in an organization, in accordance with their respective authorities and responsibilities in order to achieve organizational goals (Prawirosentono, 1999). If the individual's performance is good, it is likely that the company or organization's performance will be good. According to Levbinson (1979), performance is the achievement or achievement of a person with respect to the tasks assigned to him. Mathis and Jackson (2001) have the view that performance is a function of ability, effort and support. Muogbo (2013) states that the importance of reward in daily performance, workers cannot overestimate, especially when it comes to getting results for the work done. Gomes (2003: 171) defines motivation as behavior that is aimed at goals. Teck Hong and Waheed in Maharjan (2012) show that hygiene factors are motivators for salesperson job satisfaction. Robbins (2006: 103) defines job satisfaction as an individual's general attitude towards his job. According to Rivai and Sagala (2009: 856) the notion of job satisfaction is an assessment that reflects a person feeling happy or unhappy, satisfied or dissatisfied in taking a job. McShane and Von Glinow (2008) state that job satisfaction is an individual evaluation of the task and the work context. Dole and Schroeder (2001) in Koesmono (2005) job satisfaction can be defined as a person's reactions and feelings to the work environment.

\subsection{Work productivity}

Work productivity is the best ratio between the results obtained and the number of labor resources used. In connection with that productivity is said to be high if the process takes place according to procedures and mechanisms that are precise and accurate or the best value in carrying out a job. Activities to increase productivity must start from efforts to generate motivation or motivation to succeed in carrying out work based on awareness. According to Syarif (1991: 1) work productivity is "the relationship between the quality produced and the amount of work done to achieve results". Meanwhile, according to Hasibuan (2001: 94) Work productivity is "the comparison between output and input where the output must have added value and better processing techniques". Based on the description above, work productivity is the best comparison between the results obtained (output) and the number of work sources used (input) so that the work carried out can achieve maximum results.

\subsection{Work ability}

Ability to show the potential of people to carry out a task or job is a manifestation of their knowledge and skills. Therefore, employees who have high abilities can support the achievement of the vision and mission of the organization to move forward and develop rapidly, in order to anticipate global competition. The abilities that a person has will make him different from those who have average or ordinary abilities. According to Thoha (2011) ability is one element of maturity related to knowledge or skills that can be obtained from education, training and an experience. According to Kaleta (2006: 170) work ability refers to a complex feature and the level reflects the interaction between the volume of both physical and mental activities and the functional abilities of workers. their health and a subjective assessment of their status in a given organizational and social condition. Soelaiman (2007: 112) states that ability is a trait that is born or learned that allows a person to complete his work, both mentally and physically. According to Robbins (2006: 52), work ability is an individual's capacity to carry out various tasks in a particular job. Where individual abilities are essentially composed of two factors, namely: intellectual abilities and physical abilities. According to Robbins (2006: 52), work ability is an individual's capacity to carry out various tasks in a particular job. Where individual abilities are essentially composed of two factors, namely: intellectual abilities and physical abilities. According to Robbins (2006: 52), work ability is an individual's capacity to carry out various tasks in a particular job. Where individual abilities are essentially composed of two factors, namely: intellectual abilities and physical abilities.

\subsection{Work motivation}

The definition of motivation according to Rivai (2004: 455) is "A series of attitudes and values that influence individuals to achieve specific things in accordance with individual goals. These attitudes and values are invisible which provide the strength to encourage individuals to behave in achieving their goals. The encouragement consists of 2 (two) components, namely: the direction of behavior (work to achieve goals), and the strength of behavior (how strong the individual effort at work)". According to Winardi (2004: 6) motivation is "a potential power that exists within a human being, which he can develop himself or be developed by a number of outside forces which essentially revolve around monetary rewards and non-monetary rewards, which can affect the results of his performance either positively or negatively, which depends on the situation and 
conditions faced by the person concerned". The definition of motivation according to Usmara (2006: 14) is "a collection of power that comes from both inside and outside the individual who initiates an attitude and determines its shape, direction and intensity".

\subsection{Research Framework}

The development of cooperatives is currently supported by the development of small and medium enterprises in Pasuruan, especially in the city of Pasuruan, which is growing rapidly. In line with the increasing economy of the people in Pasuruan City, cooperatives are expected to help provide funds to finance and develop industrial, agricultural, trade and other nonfinancial sectors. Therefore the cooperative has the responsibility to produce high work productivity through reliable and competitive employee performance. So that in the end it will produce high work productivity as well.

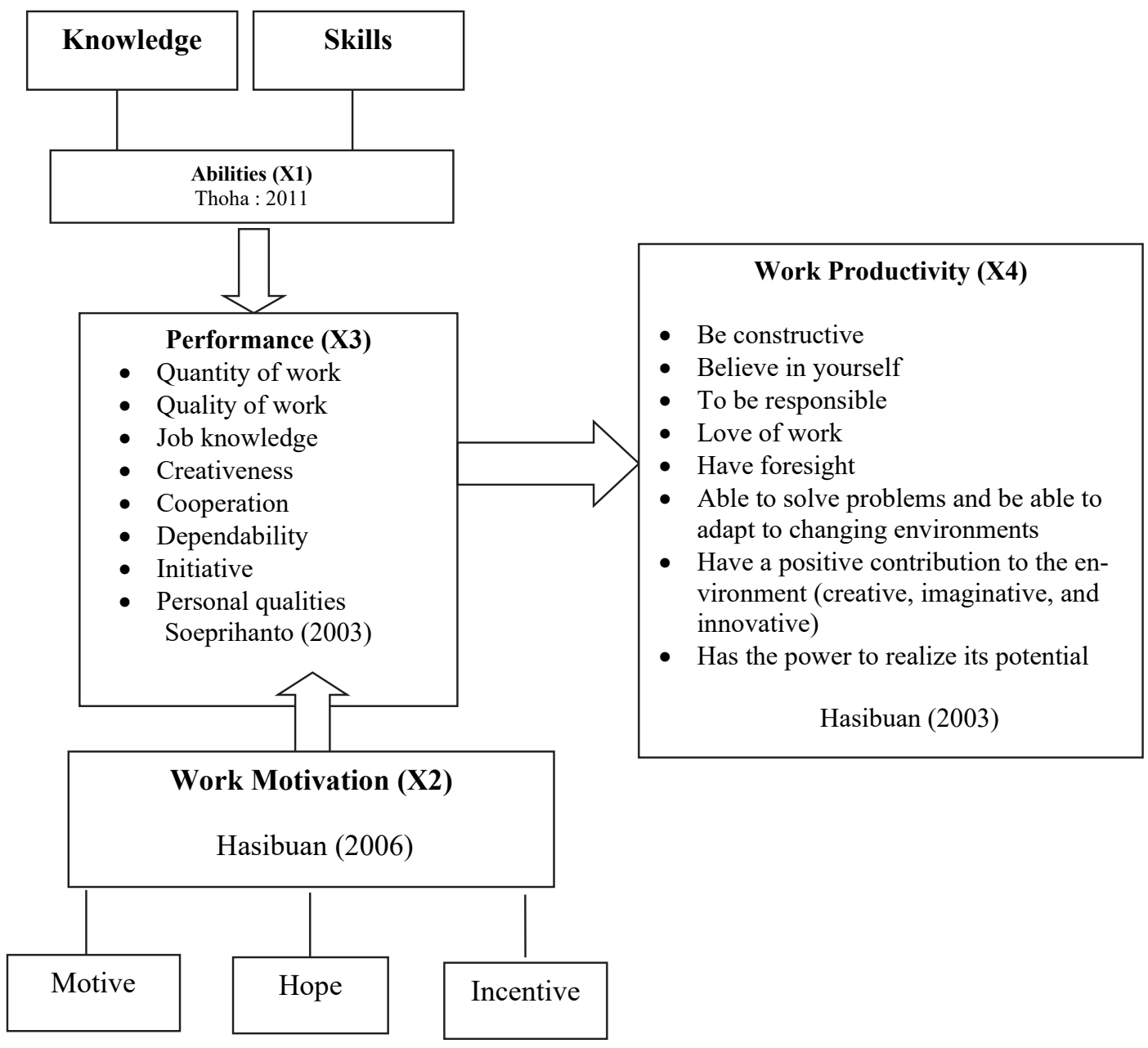

\subsection{Hypothesis}

Fig. 1. Research Framework

Based on this framework, the authors formulate the following research hypothesis:

1) Work ability and work motivation have significant contributions to performance.

2) Work ability, work motivation and performance have significant effects on productivity.

3) Work ability has a direct and significant effect on performance.

4) Work motivation has a direct and significant effect on performance.

5) Work ability has a direct and significant effect on productivity.

6) Work motivation has a direct and significant effect on productivity.

7) Performance has a direct and significant effect on productivity.

8) Work ability has an indirect and significant effect on productivity through performance.

9) Work motivation has an indirect and significant effect on productivity through performance. 


\section{Methodology}

\subsection{Research design}

In accordance with the objectives to be achieved in this study, namely explaining the influence of several research variables and testing predetermined hypotheses, the type of research used is explanatory research (Singarimbun \& Effendi, 2005). This study identifies facts or events as the affected variable (dependent variable) and conducts investigations on the influencing variables (independent variable). With the survey method, namely trying to explain the causal relationship and testing the relationship between the variables of ability, work motivation, performance and work productivity.

\subsection{Operational Definition of Variables}

a. Abilities (X1)

Ability is the individual's capacity to perform various tasks in a job. The existing elements relate to the knowledge or skills that can be obtained from education, training and experience (According to Thoha, 2011). Ability indicators, namely knowledge and abilities.

b. Work Motivation (X2)

Work motivation is an impulse or desire in a person that causes the person to act for a reason to achieve goals (Hasibuan 2006: 162). The indicators are as follows; motives, expectations and incentives.

c. Performance (X3)

Performance is the result of an employee's work during a certain period compared to the possibility, for example, standards, targets or work targets that have been determined in advance and have been mutually agreed upon (Soeprihanto: 2003). The indicators used are quantity, quality of work, work knowledge, creativity or creative power, cooperation, linkages and initiatives.

d. Work Productivity (X4)

Work productivity is the best ratio between the results (output and input) obtained with the number of labor sources used (Hasibuan, 2003: 126). In connection with that productivity is said to be high if the process takes place according to procedures and mechanisms that are precise and accurate or the best value in carrying out a job. Activities to increase productivity must start from efforts to generate motivation or motivation to succeed in carrying out work based on awareness. The indicators used are; act constructively, believe in yourself, take responsibility, love your job, have a forward view, are able to solve problems, have a positive contribution to the environment, have the power to realize their potential.

\subsection{Population and Research Sample}

The population of this study includes all cooperative heads in the Pasuruan City area who are still active in business. According to data from the Department of Cooperatives in Pasuruan City, the number of cooperatives is 289 cooperatives. While the study took a total sample of 99 cooperatives that are still active (reporting RAT for 2 consecutive years).

\subsection{Data analysis method}

The analysis technique used in this research is path analysis. Path analysis is the development of linear regression which is used to test the amount of contribution intended for the path coefficient on each path diagram of the causal relationship between variables (Retherford, 1993). Testing is assisted by SPSS 23 software, the magnitude of the influence of the independent variables on the dependent variable will be known.

\section{Results and discussion}

\subsection{Path Analysis}

Hypothesis testing in this study begins with testing the suitability of the model, in which the path diagram has been previously established which describes the relationship between variables. Path diagrams are used to see the magnitude of the influence of each variable, either directly or indirectly, on the productivity of cooperatives in Pasuruan City. After forming a model based on theory, a path analysis model is obtained so that a path diagram can be built. Path diagram is used to see the causality relationship to be tested.

Table 1

Relations Between Variables

\begin{tabular}{|c|c|c|c|c|}
\hline \multicolumn{3}{|c|}{ Variable } & Coefficient & Nature of Relationships \\
\hline Work ability & $\rightarrow$ & Performance & 0.470 & Live \\
\hline Work motivation & $\rightarrow$ & Performance & 0.392 & Live \\
\hline Performance & $\rightarrow$ & Productivity & 0.542 & Live \\
\hline Work ability & $\rightarrow$ & Productivity & 0.578 & Live \\
\hline Work motivation & $\rightarrow$ & Productivity & 0.595 & Live \\
\hline Work ability & $\rightarrow$ & Productivity & 0.255 & Indirect \\
\hline Work motivation & $\rightarrow$ & Productivity & 0.213 & Indirect \\
\hline
\end{tabular}


Based on the relationship between variables in Table 1, it is known that there are 7 paths (paths), consisting of 5 direct relationship paths and 2 indirect relationship paths. In this case, a direct relationship is the relationship between one variable and another without an intermediary variable, while an indirect relationship is a relationship between one variable and another through an intermediate variable.

\subsection{Hypothesis testing}

Hypothesis testing is done by analyzing the amount of regression weights. This analysis was conducted to show the magnitude of the simultaneous effect, direct effect and indirect effect of one variable with another, with the following decision-making criteria:

- If the p-value (significance value) $<\alpha 0.05$ then $\mathrm{H} 0$ is rejected.

- If the p-value (significance value) $>\alpha 0.05$ then $\mathrm{H} 0$ is accepted.

In this study, there were 2 simultaneous tests, namely work ability and motivation to performance and work ability, work motivation and performance on productivity. Simultaneous testing is carried out using the F test.The following are the simultaneous test results and the hypotheses tested:

1) Hypothesis Test 1

$\mathrm{H}_{0}$ : There is no effect of work ability and motivation on performance.

$\mathrm{H}_{1}$ : Either work ability or work motivation has an effect on performance.

Table 2

Structural Model Simultaneous Test Results 1

\begin{tabular}{lcccc}
\multicolumn{1}{c}{ Model } & Sum of Squares & Free Degrees & Middle Square & Test Statistics F \\
\hline Regression & 2336.613 & 2 & 1168.307 & Value of Significance \\
Residual & 4614.897 & 102 & 45.244 & 0.000 \\
\hline Total & 6951.510 & 104 & & \\
\hline *: significant at 5\% real level & & & &
\end{tabular}

As shown in Table 2, the simultaneous test results for structural model 1 obtained a significance value of 0.000 and $\mathrm{H}_{0}$ is rejected. That is, there is a significant effect of work ability and work motivation on the performance of cooperatives in Pasuruan City. Based on the results of regression analysis, the R-Square value for modeling work ability and motivation to performance is 0.226 . This means that the contribution of work ability and work motivation to performance is only $22.6 \%$, while the remaining $77.4 \%$ is explained by other variables outside the model.

2) Hypothesis Test 2

$\mathrm{H}_{0}$ : There is no effect of work ability, motivation and performance on productivity.

$\mathrm{H}_{1}$ : Either work ability, work motivation or performance has an effect on productivity.

Table 3

Structural Model Simultaneous Test Results 2

\begin{tabular}{lcccc}
\hline Model & Sum of Squares & Free Degrees & Middle Square & Test Statistics F \\
\hline Regression & 10567.563 & 3 & 3522.521 & Value of Significance \\
Residual & 11419.218 & 101 & 113.062 & \\
\hline Total & 21986.781 & 104 & & \\
\hline *: significant at 5\% real level & & & &
\end{tabular}

The results of simultaneous testing of structural model 2 in Table 3 produce a significance value of 0.000 , where the significance value is smaller than the $5 \%$, so $\mathrm{H}_{0}$ is rejected. This means that at least work ability, work motivation or performance has a significant effect on the productivity of cooperatives in Pasuruan City. Based on the results of the regression analysis, the R-Square value for modeling work ability, motivation and performance on productivity is 0.481 . This means that the contribution of work ability, work motivation and performance to productivity is only $48.1 \%$, while the remaining $51.9 \%$ is explained by other variables outside the model. The following is the path coefficient and the significance value of the direct effect of the path model that has been formed:

Table 4

Results of the Direct Effect Weight Regression

\begin{tabular}{|c|c|c|c|c|}
\hline Path & Unstandardized Beta & Standardized Beta & Value of Significance & Decision \\
\hline Work ability $\rightarrow$ Performance & 0.470 & 0.227 & $0.007 *$ & Significant \\
\hline Work motivation $\rightarrow$ Performance & 0.392 & 0.464 & $0.000 *$ & Significant \\
\hline Performance $\rightarrow$ Productivity & 0.542 & 0.305 & $0.000 *$ & Significant \\
\hline Work ability $\rightarrow$ Productivity & 0.578 & 0.157 & $0.043 *$ & Significant \\
\hline Work motivation $\rightarrow$ Productivity & 0.595 & 0.395 & $0.000 *$ & Significant \\
\hline
\end{tabular}

*: significant at $5 \%$ real level 
3) Hypothesis Test 3

$\mathrm{H}_{0}$ : There is no direct effect of work ability on performance.

$\mathrm{H}_{1}$ : There is a direct effect of work ability on performance.

Based on the test results, it is known that the direct effect of work ability has a significance value of $0.007 \mathrm{and} \mathrm{H}_{0}$ is rejected. It can be concluded that the direct effect of work ability is significant on the performance of cooperatives in Pasuruan City. The path coefficient of the direct effect of work ability on performance is 0.470 .

4) Hypothesis Test 4

$\mathrm{H}_{0}$ : There is no direct effect of work motivation on performance.

$\mathrm{H}_{1}$ : There is a direct effect of work motivation on performance.

The path coefficient of the direct effect of work motivation on performance is 0.392 , because it is positive, meaning that the relationship between work motivation and performance is positive. As shown in Table 4 testing the direct effect obtains a significance value of 0.000 . Because the significance value is smaller than the $5 \%, \mathrm{H} 0$ is rejected. This means that the direct effect of work motivation is significant on the performance of cooperatives in Pasuruan City.

5) Hypothesis Test 5

$\mathrm{H}_{0}$ : There is no direct effect of work ability on productivity.

$\mathrm{H}_{1}$ : There is a direct effect of work ability on productivity.

The path coefficient of the direct effect of work ability on productivity is 0.578 , because it is positive, which means that the relationship between work ability and productivity is positive. Shown in Table 4 testing the direct effect obtained a significance value of 0.043 . Because the significance value is smaller than the $5 \%$ real level, H0 is rejected. This means that the direct effect of work ability is significant on the productivity of cooperatives in Pasuruan City.

6) Hypothesis Test 6

$\mathrm{H}_{0}$ : There is no direct effect of work motivation on productivity.

$\mathrm{H}_{1}$ : There is a direct effect of work motivation on productivity.

Based on the test results, it is known that the direct effect of work motivation has a significance value of 0.000 . The significance value is smaller than the $5 \%$, then $\mathrm{H}_{0}$ is rejected. It can be concluded that the direct effect of work motivation is significant on the productivity of cooperatives in Pasuruan City. The path coefficient of the direct effect of work motivation on productivity is 0.595 . The form of direct relationship between work motivation and productivity is positive. This is because the path coefficient value obtained is positive.

7) Hypothesis Test 7

$\mathrm{H}_{0}$ : There is no direct effect of performance on productivity.

$\mathrm{H}_{1}$ : There is a direct effect of performance on productivity.

The path coefficient of the direct effect of performance on productivity is 0.542 , because it is positive, meaning that the relationship between performance and productivity is positive. As shown in Table 4 testing the direct effect obtains a significance value of 0.000 . Because the significance value is smaller than the $5 \%, \mathrm{H}_{0}$ is rejected. This means that the direct effect of performance is significant on the productivity of cooperatives in Pasuruan City.

Table 5

Results of the Regression Weight Indirect Effect

\begin{tabular}{|c|c|c|c|c|c|}
\hline Path & Unstandardized Beta & Standardized Beta & Standard Error & Statistical Value t & Decision \\
\hline Work ability $\rightarrow$ Performance $\rightarrow$ Productivity & 0.255 & 0.069 & 0.122 & $2,083 *$ & Significant \\
\hline Work ability $\rightarrow$ Performance $\rightarrow$ Productivity & 0.213 & 0.141 & 0.072 & $2,921 *$ & Significant \\
\hline$*$ : significant at $5 \%$ real level & & & & & \\
\hline
\end{tabular}

\section{The calculation of the statistical value of the t test}

Sa: Standard error of the path coefficient of work ability to performance, Sb: Standard error path coefficient of work motivation on performance, Sc: Standard error of the path coefficient of performance to productivity, a: the path coefficient of the direct effect of work ability on performance, b: path coefficient of the direct effect of work motivation on performance, c: path coefficient of the direct effect of performance on productivity. 
Table 6

Standard Error Value and Direct Effect Path Coefficient

\begin{tabular}{cccc}
\hline Standard Error & Score & Path Coefficient & Score \\
\hline $\mathrm{Sa}$ & 0.175 & $\mathrm{a}$ & 0.470 \\
$\mathrm{Sb}$ & 0.072 & $\mathrm{~b}$ & 0.392 \\
$\mathrm{Sc}$ & 0.154 & $\mathrm{c}$ & 0.542 \\
\hline
\end{tabular}

Calculation of the combined standard error is based on the following formula:

$S_{a b}=\sqrt{b^{2} S_{a}^{2}+a^{2} S_{b}^{2}+S_{a}^{2} S_{b}^{2}}$

then the standard error value for the indirect effect above is:

$\mathrm{S}_{\mathrm{ac}}$ : Standard error of the path coefficient of work ability to productivity through performance.

$\mathrm{S}_{\mathrm{bc}}$ : Standard error path coefficient from work motivation to productivity through performance.

Table 7

Standard Error Indirect Effet Value

\begin{tabular}{cc}
\hline Standard Error & Score \\
\hline $\mathrm{S}_{\mathrm{ac}}$ & 0.122 \\
$\mathrm{~S}_{\mathrm{bc}}$ & 0.073 \\
\hline
\end{tabular}

Calculation of the combined standard error is based on the following formula:

$t_{a b}=\frac{a b}{S_{a b}}$

8) Hypothesis Test 8

$\mathrm{H}_{0}$ : There is no indirect effect of work ability on productivity through performance.

$\mathrm{H}_{1}$ : There is an indirect effect of work ability on productivity through performance.

The path coefficient of the indirect effect of work ability on productivity through performance is 0.255 . As shown in Table 5 , the indirect effect test obtained the t-test statistic value of 2.083. Because the t-test statistic value is greater than the t-table value at the $5 \%$ and $n-1$ degrees of freedom, $\mathrm{H}_{0}$ is rejected. It can be said that there is an indirect effect of work ability on the productivity of cooperatives in Pasuruan City. That is, significant performance acts as an intermediary variable.

9) Hypothesis Test 9

$\mathrm{H}_{0}$ : There is no indirect effect of motivation on productivity through performance.

$\mathrm{H}_{1}$ : There is an indirect effect of motivation on productivity through performance.

The path coefficient of the indirect effect of work motivation on productivity through performance is 0.213 . As shown in Table 5, the indirect effect test obtained the t test statistic value of 2.921. Because the t-test statistic value is greater than the t-table value at the $5 \%$ and $n-1$ degrees of freedom, $\mathrm{H}_{0}$ is rejected. It can be said that there is an indirect effect of work motivation on the productivity of cooperatives in Pasuruan City. That is, significant performance acts as an intermediary variable.

\subsection{Model Interpretation}

The path coefficient value of the work ability variable on the cooperative's performance in Pasuruan City is 0.470 . This shows that the variable of work ability affects the performance of cooperatives in Pasuruan City by $47 \%$. The positive value of the path coefficient indicates that the relationship between work ability and cooperative performance in Pasuruan City is positive. This means that the higher the work capacity of the cooperative in Pasuruan City, the higher the cooperative's performance will be. The value of the path coefficient (path) variable work motivation on cooperative performance in Pasuruan City is 0.392. This shows that the work motivation variable affects the cooperative performance in Pasuruan City by $39.2 \%$. The positive value of the path coefficient indicates that the relationship between work motivation and cooperative performance in Pasuruan City is positive. This means that the higher the work motivation of the cooperative in Pasuruan, the higher the cooperative's performance. The value of the path coefficient of the performance variable on the productivity of the cooperative in Pasuruan City is 0.542 . This shows that the performance variable affects the productivity of the cooperative in Pasuruan City by $54.2 \%$. The positive value of the path coefficient indicates that the relationship between performance and cooperative productivity in Pasuruan City is positive. This means that the higher the performance of the cooperative in Pasuruan, the higher the productivity of the cooperative. The path coefficient value of the work ability variable on the productivity of the cooperative in Pasuruan City is 0.578 . This shows that the work ability variable affects the productivity of cooperatives in Pasuruan City by $57.8 \%$. The positive value of the path coefficient indicates that the relationship between work ability and 
cooperative productivity in Pasuruan City is positive. This means that the higher the working ability of the cooperative in Pasuruan City, the higher the productivity of the cooperative.

The value of the path coefficient (path) variable of work motivation on cooperative productivity in Pasuruan City is 0.595 . This shows that the work motivation variable affects the productivity of cooperatives in Pasuruan City by $59.5 \%$. The positive value of the path coefficient indicates that the relationship between work motivation and cooperative productivity in Pasuruan City is positive. This means that the higher the work motivation of the cooperative in Pasuruan City, the higher the productivity of the cooperative.

Based on these results, it is known that the relationship that has the greatest direct influence is work motivation on the productivity of cooperatives in Pasuruan, which is 59.5\%. This is in line with the theory which states that the higher the work motivation of the members and management of the cooperative, the higher the productivity of the cooperative. The effect of work ability variables on productivity through performance obtained a path coefficient of 0.255 . This shows that the ability to work through performance has an effect on productivity by $25.5 \%$. The positive value of the path coefficient indicates that the relationship between work ability and productivity through the performance of cooperatives in Pasuruan City is positive. This means that the higher the work capacity of the cooperative in Pasuruan City, the higher the performance so that the productivity of the cooperative will be higher. The influence of work motivation variables on productivity through performance obtained a path coefficient of 0.213 . This shows that work motivation through performance has an effect on productivity by $21.3 \%$. The positive value of the path coefficient indicates that the relationship between work motivation and productivity through the performance of cooperatives in Pasuruan City is positive. This means that the higher the work motivation of the cooperative in Pasuruan City, the higher the performance so that the productivity of the cooperative will be higher. Of the two forms of indirect relationship above, the relationship between the variable of work ability and productivity through the performance of cooperatives in Pasuruan City which has the greatest influence is $25.5 \%$. This means that the productivity of cooperatives in Pasuruan City will increase if the cooperative management's performance is good. In improving performance, the role of work ability is very important. By using the path coefficient, the structural equation of the path model can be formed as follows:

$$
\begin{aligned}
& \text { Performance }=0.470 \text { work ability }+0.392 \text { work motivation }+\mathrm{e} 1 \\
& \text { Productivity }=0.578 \text { work ability }+0.595 \text { work motivation }+0.542 \text { performance }+\mathrm{e} 2
\end{aligned}
$$

Based on this equation, it can be interpreted for each variable as follows:

1. In the first equation, a positive path coefficient value indicates that the variables of work ability and work motivation have a positive effect on the performance of cooperatives in Pasuruan City.

2. In the second equation, the path coefficient shows the variables of work ability, work motivation, and performance have a positive effect on the productivity of cooperatives in Pasuruan City.

The coefficient of determination is a coefficient that explains how much a dependent variable can be explained by the independent variables involved in the research. The structural model (1) obtains a coefficient of determination of 0.226 , so the magnitude of the effect of error (1) is

$$
e_{1}=\sqrt{1-R 1^{2}}=\sqrt{1-0.336}=0.815
$$

while the structural model (2) obtains a coefficient of determination of 0.481 , so the magnitude of the effect of error (2) is

$$
e_{2}=\sqrt{1-R 2^{2}}=\sqrt{1-0.481}=0.720
$$

The overall coefficient of determination can be obtained as follows

$$
R_{m}^{2}=1-\left(e_{1} \times e_{2}\right)=1-(0.815 \times 0.720)=0.413
$$

This means that the diversity of cooperative productivity in Pasuruan City can be explained by variables of work ability, work motivation and performance, either directly or indirectly, which is only $41.3 \%$, while $58.7 \%$ is explained by other variables not involved in the model.

\subsection{Discussion}

This study has aimed to determine how the contribution of work ability, work motivation, and performance to the productivity of cooperatives in Pasuruan City. Based on the analysis, it is known that work motivation has a more dominant effect than work ability on the performance of cooperatives in Pasuruan City. This is indicated by the significance value of work motivation which is smaller than the work ability. In addition, it is supported by the standardized regression coefficient value, for work motivation of 0.464 is greater than the work ability of 0.227 . The contribution of work ability and work motivation to performance is only $22.6 \%$, while the remaining $77.4 \%$ is explained by other variables. 
The work ability variable has a direct univariable effect on the performance and productivity of cooperatives in Pasuruan City. The regression coefficient of work ability on performance is 0.470 , while the regression coefficient of work ability on productivity is 0.578 . Meanwhile, the indirect effect of work ability on productivity through the performance of cooperatives in Pasuruan City is 0.255. The results of this study support Aisha (2013), Aseanty (2016), Indrayani and Wahyudi (2020) which state that work ability has an effect on performance.

The work motivation variable also has a direct univariable effect on the performance and productivity of cooperatives in Pasuruan City. The regression coefficient of work motivation on performance is 0.392 while the regression coefficient of work motivation on productivity is 0.595 . Meanwhile, the indirect effect of work motivation on productivity through the performance of cooperatives in Pasuruan City is 0.213 . Work motivation has a more dominant effect on both performance and productivity than work motivation. The results of this study support Aisha (2013) which states that motivation has an effect on performance. The results of this study also support Aseanty (2016), Al-Musadieq et al. (2018), Dewi \& Wibowo (2020), Indrayani \& Wahyudi (2020) which state that motivation affects employee performance.

The work motivation variable also has a direct univariable effect on the performance and productivity of cooperatives in Pasuruan City. The regression coefficient of work motivation on performance is 0.392 while the regression coefficient of work motivation on productivity is 0.595 . While the indirect effect of work motivation on productivity through cooperative performance in Pasuruan City is 0.213 . Work motivation has a more dominant effect on both performance and productivity than work motivation.

The contribution of work ability and work motivation to productivity through cooperative performance in Pasuruan City is $41.3 \%$, while the remaining $58.7 \%$ is explained by other variables. It appears that the performance variable acts as a moderator. It can be seen that the indirect relationship between work ability and work motivation on productivity through performance has a significant effect.

\section{Conclusion and recommendations}

\subsection{Conclusion}

Based on the results and discussion, several things can be concluded, including:

1. Work ability and motivation have positive and significant effects on cooperative performance in Pasuruan City with a significance value of 0.000 and a contribution of $22.6 \%$.

2. Work ability, work motivation and performance have positive and significant effects on the productivity of cooperatives in Pasuruan City with a significance value of 0.000 and a contribution of $48.1 \%$.

3. Work ability has a positive and significant direct effect on cooperative performance in Pasuruan City with a significance value of 0.007 and a regression coefficient of 0.470 and a standardized regression coefficient of 0.227 .

4. Work motivation has a positive and significant direct effect on cooperative performance in Pasuruan City with a significance value of 0.000 and a regression coefficient of 0.392 and a standardized regression coefficient of 0.464 .

5. Work ability has a positive and significant direct effect on the productivity of cooperatives in Pasuruan City with a significance value of 0.043 and a regression coefficient of 0.578 and a standardized regression coefficient of 0.157 .

6. Work motivation has a positive and significant direct effect on the productivity of cooperatives in Pasuruan City with a significance value of 0.000 and a regression coefficient of 0.595 and a standardized regression coefficient of 0.395 .

7. Performance has a positive and significant direct effect on the productivity of cooperatives in Pasuruan City with a significance value of 0.000 and a regression coefficient of 0.542 and a standardized regression coefficient of 0.305 .

8. Work ability has a positive and significant indirect effect on productivity through the performance of cooperatives in Pasuruan City with a test statistic value of 2.083 greater than the t table value of 1.983 and a regression coefficient value of 0.255 and a standardized regression coefficient of 0.069 .

9. Work motivation has a positive and significant indirect effect on productivity through the performance of cooperatives in Pasuruan City with a test statistic value of 2,921 greater than the t table value of 1.983 and the regression coefficient value of 0.213 and the standardized regression coefficient of 0.141 .

\subsection{Recommendations}

Based on the results of the analysis, it is known that the dominant variable on both the performance and productivity of cooperatives in Pasuruan City is work motivation. The researchers provide suggestions to related parties to improve performance and productivity, activities that focus on work motivation are carried out. In order to broaden the research results, a broader scope of research needs to be carried out, for example in the City and District of Pasuruan and by increasing the number of samples. In addition, more complex analysis can be carried out so that the information obtained is maximized, for example, the analysis of "Structural Equation Modeling". 


\section{References}

Aisha, A. (2013). Effects of working ability, working condition, motivation and incentive on employees multi-dimensional performance. International Journal of Innovation, Management and Technology, 4(6), 77-83.

Al-Musadieq, M., Nurjannah, K.R. K., Solimun \& Fernanes, A. R. F. (2018). The mediating effect of work motivation on the influence of job design and organizational culture against HR performance. Journal of Management Development, 37(6), 452-469.

Aseanty, D. (2016). Impact of working ability, motivation and working condition to employee's performance; Case in private universities in west Jakarta. OIDA International Journal of Sustainable Development, 9(4), 35-42.

Dewi, N., \& Wibow, R. (2020). The effect of leadership style, organizational culture and motivation on employee performance. Management Science Letters, 10(9), 2037-2044.

Gomes, F. C. (2003). Manajemen Sumber Daya Manusia. Jakarta. Andi Offset.

Hasibuan, M. (2001). Manajemen Sumber Daya Manusia. Jakarta. PT Bumi. Aksara.

Indrayani, I \& Wahyudi, D. (2020). Environmental management performance and the role of human resources management: Empirical study in quaternary economic sector. Management Science Letters, 10(16). 3967-3974.

Kaleta, D. (2006). Lifestyle index and work ability. International Journal of Occupational Medicine and Environmental Health, 19(3). 170-177.

Koesmono, H. T. (2005). Pengaruh Budaya Organisasi Terhadap Motivasi dan Kepuasan Kerja serta Kinerja Karyawan Pada Sub Sektor Industri Pengolahan Kayu Skala Menengah Di Jawa Timur. Jurnal Manajemen \& Kewirausahaan, 7(2). 171188 .

Mathis, L. R \& Jackson, .H. J. (2001). Manajemen Sumber Daya Manusia. Jakarta. Salemba Empat.

Muogbo. (2013). The impact of employee motivation on organisational performance (A Study Of Some Selected Firms In Anambra State Nigeria). The International Journal Of Engineering And Science (IJES), 2(7), 70-80.

Prawirosentono, S. (1999). Kebijakan Kinerja Karyawan. Yogyakarta. BPFE.

Rivai, V \& Sagala, E. J. (2009). Manajemen Sumber Daya. Manusia untuk Perusahaan dari Teori ke Praktik. Jakarta. PT Raja. Grafindo.

Robbins, S. (2006). Essentials of Organizational Behaviour. New Jersey: Prentice-Hall, inc.

Soelaiman. (2007). Manajemen Kinerja: Langkah Efektif untuk Membangun, Mengendalikan dan Evaluasi Kerja. Jakarta. PT. Intermedia.

Soeprihanto, J. (2001). Penilaian Kinerja dan Pengembangan Karyawan. Yogyakarta. BPFE.

Syarif, R. (1991). Produktivitas. Bandung. Penerbit Angkasa.

Thoha, M. (2011). Perilaku Organisasi Konsep Dasar dan Aplikasinya. Jakarta. Rajawali Grafindo Persada.

Usmara, A. (2006). Paradigma Baru Manajemen Sumber Daya Manusia. Yogyakarta. Amara Books.

Winardi. (2004). Manajemen Perilaku Organisasi. Jakarta. Kencana Prenada Media Group.

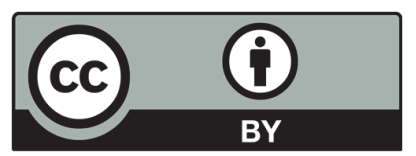

(C) 2020 by the authors; licensee Growing Science, Canada. This is an open access article distributed under the terms and conditions of the Creative Commons Attribution (CC-BY) license (http://creativecommons.org/licenses/by/4.0/). 